\title{
Religious live-streaming in response to coronavirus disease 2019 pandemic and the subsequent lockdown in South Africa
}



The novel coronavirus disease 2019 (COVID-19) is a virus that firstly struck in Wuhan, China, but its impact is felt by the whole world. The spread of the virus in South Africa caused President Cyril Ramaphosa to announce a national state of disaster in the country on 15 March 2020. Subsequently, on 23 March 2020, the President announced a total shutdown of the economy, which is also known as lockdown, effective from 26 March 2020. The restrictions of the lockdown affected different churches regardless of the denomination name. Churches were not allowed to congregate during this period for the safety of their followers and the citizens. This article reflects on the use of live-streaming via social media platforms such as zoom, Twitter, Facebook, YouTube and other apps by many churches in South Africa as a response or a way of coping with the lockdown. The argument is that although these various platforms proved to be effective on the one hand, they also raised other challenges on the other hand. The article will look at the ways of mediating the challenges of live-streaming and make recommendations.

Intradisciplinary and/or interdisciplinary implications: The article is an interdisciplinary study between theology and media studies. The study seeks to demonstrate how churches used live-streaming via social media to cope with the restrictions of the lockdown in South Africa.

Keywords: coronavirus disease 2019; COVID-19; lockdown; social media; religion; Churches; World Health Organization; live-streaming.

\section{Introduction}

The novel coronavirus disease 2019 (COVID-19) started in Wuhan, China, as a cluster of pneumonia cases. Severe acute respiratory syndrome coronavirus 2 (SARS-CoV-2) causes COVID-19, according to the World Health Organization (WHO) (2020). What started as a Chinese virus soon spread to other parts of the world with most of the European countries and later the United States of America and Southern America as the epicentre of COVID-19. In South Africa, according to the National Institute of Communicable Diseases (NICD) (2020), the first case of COVID-19 was confirmed on 05 March 2020 on a 38-year-old male South African who had travelled to Italy together with his wife. Soon after the confirmation of the first case, the virus began to spread to other parts of the country with many metropolitan areas identified as hotspots. The spread of the virus according to the South African government (2020) caused President Ramaphosa to announce the national state of disaster and, subsequently, the national lockdown. There is already a growing interest by scholars to study COVID-19. The contribution of this article is a reflection on the response of churches to the restrictions of the lockdown. The article will use media content analysis to analyse live-streaming via various social media platforms to assess their effectiveness in addressing the lack of physical fellowship during the lockdown. The article will also highlight the challenges with regard to these various platforms and recommend the way forward.

\section{The lockdown in South Africa}

Because of lack of the vaccine to deal with spread COVID-19, most countries of the world implemented the lockdown (see Buheji et al. 2020:213). Moreover, in the words of Jaja, Anyanwu and Iwu Jaja (2020:1077), 'the health care system and disease preparedness in the majority of the 54 African nations are virtually absent'. Similarly, as the virus began to spread in South Africa during March, President Cyril Ramaphosa announced a national state of disaster on 15 March 2020. 
On 23 March 2020, the President announced a total shutdown of the economy, which is also known as lockdown, that became effective from 26 March 2020. Some restrictive measures that were imposed to control the spread of the disease according to Ozili (2020a) include:

$[R]$ estricting non-essential activities, closing schools and universities, encouraging people to stay home, the lockdown of entire cities, requiring essential businesses to run skeletal operations and employees should work from home. (p. 1)

Other measures according to Fosu and Edunyah (2020:4) included 'closure of borders, halting airline operations, enforcing distances between persons, restricting movement of people, quarantining affected and exposed persons, fumigation and continual sanitizing of hands and frequent hands washing'. In addition, the government according to Dyer (2020:1) implemented very strict measures during the lockdown that included a ban on tobacco to prevent lung diseases on individuals and alcohol to prevent abuse in families.

The concern of lockdown by many people was the burden it exerted on the livelihoods of families, as many could no longer take care of their families because of not working. Therefore, the poorest of the poor were affected by the lockdown as many depend on selling on the streets for survival. Entrepreneurs in the informal economy as they are called here in South Africa could not even access the government relief funds as many of their businesses are not registered and many do not even have banking accounts. Buheji et al. (2020:214) add that during the emergency like the lockdown, the poor are hard-hit especially as many do not have income or even the buying power to buy the necessities. In addition, many businesses were affected with some of them forced to close, as they could not afford rentals and other maintenance fees to keep afloat. Ozili (2020a:4) reports that the tourism sector in South Africa fell by $80 \%$ because of the ban on travel and related industries. Many other businesses suffered the consequence of the lockdown not only in South Africa but also in the rest of the continent as Africa depends much on human interaction than, for example, Europe (see Ozili 2020a:4).

The main challenge was the use of violence by many officials in dealing with the people who did not comply with the regulations of the lockdown. According to Dyer (2020:1), violence involved the killing of a man and the injury of three others during the lockdown. This resulted in citizens launching complaints on the police officers and soldiers because of the mistrust. According to a research conducted by Isbell (2020):

[O]nly about half $(53 \%)$ of South Africans said they trust the army, and only four in 10 (39\%) said the armed forces usually operate professionally and respect the rights of all citizens. (p. 2)

However, the officials on the streets were not the only ones to incite violence, but there was also domestic violence. There are reported scenes of violence that happened during the lockdown especially between married couples. According to Magongo (2020):

[S]outh Africa has been facing a domestic violence crisis even before the arrival of COVID-19. There is a high risk that the forced confinement and economic stress caused by COVID-19 will exacerbate the problem of domestic violence in the country. (p. 14)

Therefore, maintaining law and order was a pivotal exercise that needed to complement the health of the citizens. Another violence happened amongst community members as many of them fought for the acquisition of food during the food parcel distribution by the South African government. In some instances, this violence led to looting of shops by community members in search of food.

With all of the above-mentioned restrictions and regulations of the lockdown, the very bold question to be asked is if the lockdown was a success in South Africa. There are mixed feelings as to whether the lockdown worked in decreasing the spread of the virus or not. According to Isbell (2020), lockdown posed some challenges:

For many, accessing basic services such as water and toilets means leaving the house or even the compound. For example, about half of South Africans do not have piped water (47\%) or toilet facilities $(51 \%)$ in their homes. And while people are encouraged to work from home during the lockdown, only $58 \%$ enjoy a supply of electricity that works more than half the time. Access to basic services is unequally distributed among different groups in South Africa. While two in three urban residents (67\%) have piped water in their homes, only one in five rural residents $(22 \%)$ do. In fact, $44 \%$ of rural dwellers said they have to leave their compound to access water. (p. 4)

Isbell's study suggests that most South Africans especially those living in the rural areas needed more support in accessing the basic services to motivate them to stay indoors. However, many highlighted the fact that the spread of the various could have been more serious, had the lockdown restrictions not been implemented in South Africa. In essence, lockdown might have not been smooth in rural areas and informal settlements, but at least it prevented the spread of COVID-19 in higher percentage. In the next section, one is going to look at the impact of the lockdown on the churches.

\section{The impact of the lockdown on churches}

All churches in different denomination and other places of fellowship such as synagogues and mosques in South Africa were affected by the regulations and restrictions of the lockdown. According to Ozili (2020b:4), all religious services were prohibited during the lockdown and those who insisted on gathering were arrested by the officials. Big churches like the Zion Christian Church (ZCC) had to postpone their annual Easter pilgrimage that normally gathers millions on an annual basis. Zion Christian Church made a decision to postpose this meeting to save as many lives that would have been affected by the virus in such big gatherings. Most of the 
churches and different denominations followed suit in support of the lockdown measures. However, there was no basis of arguing against the lockdown because of the disaster management act, according to Badenhorst (2020):

From a religious freedom point of view, it is important to remember that no right in the Bill of Rights - including the right to freedom of religion (s 15), freedom of association (s 18), and the rights of cultural, religious and linguistic communities (s 31) - is absolute. In terms of s 36 of the Constitution, a law of general application may reasonably and justifiably limit any fundamental right. The applicable law in this case is the Disaster Management Act, 2002. (p. 1)

Nonetheless, the lockdown had a huge impact on different churches because the government prohibited the physical gathering. For example, most churches could not collect as many offerings during the lockdown as they do during normal church services. Pastor Jentile of Baptist Church in Mamelodi spoke to Mathe (2020:1) on the state of his church finances; he said that 'The income has dropped and we are now faced with a situation where the only person who is going to be paid a salary next month is $\mathrm{me}^{\prime}$. Actually, some of the churches were not able to pay pastors at all because the income in their churches dropped in high percentage. The pastors in these churches could not force the members to pay their tithes, as giving according to 2 Corinthians 9:7 should be voluntary, 'Each one must give as he has decided in his heart, not reluctantly or under compulsion, for God loves a cheerful giver'. Pastors can only motivate believers to pay their tithes but cannot force them to do so. However, like any other organisation in addition to paying salaries, churches had to pay other bills such as water, rates and electricity (Mathe 2020:2).

Some churches have been able to collect tithes from their members by using electronic funds transfer (EFT). However, the challenge for churches in the townships according to Pastor Jentile in Mathe (2020:3) is the lack of such facilities that would allow the payment of tithes through EFT. In addition, most of the church members give as a response to the message been preached on a particular service in the church and when they do not congregate, they do not see a need to give to the church (Mathe 2020:4). The main challenge is that the members who are actually expected to pay their tithes and offerings have actually lost their jobs and some had their businesses closed. Thus, even if they were very much willing to pay their tithes, they could not do so because of loss of income as a result of the lockdown. However, even in these challenges, Jentile in Mathe (2020) is very adamant that the church will emerge victorious. He said that:

$[N]$ o matter what change might arise from this crisis, churches will adapt. Whatever sociological change that is there, the church has always been the driver. The church will not die - it will survive. (p. 4)

Lockdown had challenges on the church not only in terms of the income of the church but also the outreach programmes in some churches. For example, the Enlightened Christian Gathering (ECG) of the controversial Prophet Shepherd Bushiri was hindered to distribute the food parcels and other essentials, as such an activity was in the bridge of the lockdown restrictions according to the police. According to Iharare (2020), ECG and Bushiri planned a high-profile event that would involve Emalahleni Mayor, Linah Malatjie, to distribute food to the residents of Emalahleni in Mpumalanga, South Africa. However, the police, who argued that the event was illegal, intercepted trucks carrying food, sanitisers and other protective equipment. At the end, the community suffered the consequences because of the grievance between ECG and the police. All of these challenges require a reflection in terms of how churches responded to them in the context of the lockdown restriction. In the next point of discussion, I discuss live-streaming via social media as a response to the impact of the lockdown on churches.

\section{Live-streaming: A response to the impact of lockdown}

Most of the churches in South Africa were able to utilise live-streaming via social media to reach their audience during the lockdown. The first example is Bushiri who has a strong social media presence on platforms such as Twitter, YouTube and Facebook. In addition, Bushiri has a prophetic channel, an official television channel of ECG that was very much active during the lockdown. However, in strategic efforts to reach larger audience, Bushiri launched an online church through his 'Major 1 connect app'. According to Bhengu (2020), the app can connect Bushiri with his choir members and other local and international congregants through video-conferencing using multiple screens. However, to connect with the prophet, the subscribers needed to pay a subscription fee of about R80.00. Bhengu (2020) continues to say that during its launch, the app had 10000 downloads and the church expects another 20000 subscribers to join the app. In one of the services, the church claimed to have 6 million in attendance with about 7000 subscribers to the app. Enlightened Christian Gathering made all these efforts to deal with the challenge of the restrictions placed on the churches during the lockdown in South Africa.

Majority of other pastors used Facebook live stream that also proved to be effective, and through software like Open Broadcaster Software (OBS) studio pastors were able to have their live-stream videos shared between Facebook, YouTube and Twitter. Other pastors were even able to use simple mediums like emails, and this worked as per the testimony of Sandisiwe Shoba (2020) below:

For me, coping with the lockdown has meant clinging to my faith. My church has done a great job of creating online resources to give our community hope and keep us connected during this time. My pastor has created a series of 'Daily Bread' videos which are sent via email each morning. Starting my day with a message of encouragement has eased a lot of the stress associated with the uncertainty of the pandemic. 
Shoba (2020) continued to illustrate how her church effectively used the zoom app during the lockdown:

Our church has also continued to gather each Sunday for a church service via Zoom. Smaller groups still meet online during the week for fellowship and Bible study. Keeping that routine of connecting with the church community has been a welcome cure for the gloom and loneliness of this season.

The message of adapting to new technology was for not only the younger generation and newer churches but also even the mainline churches. This is illustrated by the words of the Anglican Archbishop Thabo Makgoba in Charles (2020):

Our clergy in churches from St George's Cathedral to St Cyprian's, KwaLanga, are adapting their Good Friday services in many innovative ways, including through Facebook, WhatsApp, Zoom and other platforms. We all obviously regret not being with one another physically, but on the other hand, this crisis is forcing us to catch up with the modern world of young people in how we are the church.

This illustrates that live-streaming and the use of social media, in general, were non-denominational during COVID-19 and the subsequent lockdown in South Africa. This new form reached out to the masses through the new technology that almost all churches quickly adapted to during the lockdown in South Africa. However, in this article, one has identified various challenges faced by livestreaming via social media platforms. I discuss these challenges below.

\section{The challenges of live-streaming during lockdown}

The first challenge with the live-streaming of services is a lack of distinction by some churches between the message meant for the congregants and the one for the public. For example, whilst the congregants might understand the issue of tithes and offerings during COVID-19 and the lockdown, the public will not understand but perceive it to be greediness. This according to Mathe (2020:5) is what happened when Bushiri appeared on a video during the early stages of the lockdown requesting his congregants to contribute their tithes and offerings through EFTs. In another video, Bushiri promised tithe payers a prayer that will guarantee their financial well-being, health and prosperous life. The public perceived the request as being insensitive to people's loss of income and other difficulties that households faced during the lockdown. Bushiri and his church according to Mothombeni (2020) issued a statement in defence of the call for tithes and offerings:

In fact, in going online, nothing about the organisation of the church has changed; it's only the medium of reach which has changed the church still remains an organization, supported by its members, followers and well-wishers to stand and function on its own. We all know, of course, that every church, as an organisation, has recurring costs - salaries, bills, et cetera that are supposed to be met for it to function effectively. These costs, in every church, are met by contributions from willing members, followers and well-wishers voluntarily. We all know that, every church does that and, even with COVID-19, they are doing thatit's nothing unusual. (p. 1)

The church's response would also make sense to the members and followers of the church but not necessarily the public. In the public's lenses, the church and its prophet are insensitive to the plight of the people.

Another challenge that Reverend Kenneth Meshoe shared with Charles (2020) is the lack of access to these live streams specifically by residents in the informal settlements. These residents lack either proper devices or data to connect to the online services. Thus, it would not even help to send the podcasts to them. These are people who need the word of encouragement because as highlighted in 'The lockdown in South Africa' section of this article, they are the most vulnerable as they lacked food and money during the lockdown. According to the survey conducted by the Human Science Research Council (HSRC), a quarter of the residents dwelling informal settlements and even in the townships had no money to buy food (Reddy 2020). In addition, the residents in the informal settlements faced other challenges like the demolition of their shacks during the lockdown that placed them at risk of contracting COVID-19 (see Pikoli 2020). Therefore, the people in these communities cannot afford data or any other means of connectivity to view the livestreamed messages of their pastors. Consequently, the messages preached might end up being viewed by the international community than the local people who need them most.

The third challenge is the lack of quality in most of the livestreamed services because of lack of access to quality equipment that makes live-streaming appealing by small churches. This ends up affecting the message of the gospel into the ears of the listeners or viewers. According to Thompson (2020), 'livestreaming a sermon or Sunday service can be a daunting challenge, especially for small-to-mediumsized churches that lack the budget and team to execute such a production'. The challenge is not only on live-streaming for small churches but also in packaging the service itself as many issues are involved like the type of sermon, background music and so forth. Depending on the type of social media platform that the church will use, live-streaming can be costly in terms of internet connectivity. The last challenge of live-streaming services is the non-technological generation, especially the elderly in rural areas. On the contrary, evidence according to Vedfelt (2020) has shown that the elderly are the most vulnerable in terms of contracting the virus and the consequences thereof. Therefore, they need spiritual care at most, not only the message of the gospel but also to raise awareness of the disease amongst them. However, this generation in my own view are people who do not even have social media apps such as Facebook, Twitter, or YouTube on their phones and are therefore unable to view their pastors online. This brings me to the next section, mediating the challenges of live-streaming during the lockdown and even for the future. 


\section{Dealing with the challenges of live-streaming \\ Preparing with the public in mind}

The church should avoid at all costs negative publicity by conducting ministry on various live-stream mediums in a responsible manner (Kgatle 2018:5). One way to do this is to conduct live-stream services with the public in mind by making a distinction between what is meant for the congregants and for the public. In the words of Gould (2015:20), using social media in the context of the church involves knowing the content that belongs to the community in general and the Christian community. Badmos (2014:4) explains that if the church does not make such a distinction, they will expose themselves to harassment by the external forces against them. In some instances especially for churches with high usage of social media, it might result in cyber-bullying. Wielstra (2012) adds that the abuse that churches are experiencing is because of the lack of knowledge and training by various churches. In other words, churches engage in social media but do not really know the consequences of what they post on daily basis. It is for this reason that churches need to be informed about what needs to be publicised and what needs to be confidential.

\section{Remembering those in the margins}

Live-streaming should be performed in consideration of the people who are in the margins, specifically those in informal settlements and townships. Mashau (2014 cf. Mashau \& Mangoedi 2015) had already cautioned us that when doing mission in Africa, we should always be considerate about those in the margins. Similarly, when conducting live-stream services, we should remember those in the margins. These same people supported ministries when circumstances were normal and when people could congregate in a physical church. Therefore, the poor cannot be isolated during the online church. If universities are distributing data to the poor students during the lockdown, nothing stops churches to do the same to their poorest members to minister the gospel to them. Jesus did the same, he was found amongst the poor people and ministered the gospel that turned their lives around. Similarly, ministry during lockdown should be performed in consideration of the poor by not only handing food parcels to them but also ensuring that the gospel reaches them in difficult times. Another way to reach the poor is to have live-stream points where congregants can be reached in their small numbers but still adhering to the restrictions of the lockdown.

\section{Pre-recording the services}

The small churches that do not have the right equipment can opt for going the pre-recording route. This means that the messages or services can be recorded and later be broadcast as live stream. The benefit of pre-recordings is that any signs of debasement can be dealt with before the content is made public. Jones (2020) says that to deal with the challenges of live stream, churches should:

[C]onsider pre-recording different segments of their worship service using a variety of faces and locations, then publish it using streaming. Editing pre-recorded material enables changes of view and persons involved. (p. 2)

Pre-recordings will also allow churches to add background music and ensure that the content is ready to be viewed by the public. Pastors in small churches can make a request to pre-record their messages in well-established churches with full equipment and later live-stream them on their own.

\section{Encouraging family fellowships}

As highlighted above, the elders in rural areas do not have access to smartphones that would enable them to view livestreamed services. Therefore, in addition to live-streaming, the elderly need to be encouraged to fellowship in their homes, to read their bibles, pray and partake the Holy Communion on their own. A family church according to Moynagh (2014:113) has a benefit of meeting several times in the week than will do a physical church. The family group can actually move beyond servicing themselves to the mission of praying for others, communities and church (Kreider 2010). Within the context of family fellowships, the younger generation in these fellowships should help the elderly to connect the new technology in their cell phones. Alternatively, young people in households can actually use their own cell phones and other gadgets for the benefit of the elderly. All these should be performed to ensure that everyone else is connected to the Lord Jesus Christ in difficult times.

\section{Conclusion}

The novel COVID-19 is a virus that has become a pandemic affecting the nations of the whole world and has brought down many powerful economies. South Africa is one of the African countries that has received a high number of cases in the whole continent. The aim of this article was to look at the response of churches in the context of the COVID-19 outbreak and the subsequent lockdown. Many church leaders and pastors resorted to live-streaming via various social media platforms in response to the restrictions imposed on churches during the lockdown. The findings of this article are that the live-stream services in various social media platforms were very much effective in mediating between the lockdown and fellowship of the saints. However, the same live-streaming poses challenges like publicising that which is only meant for congregants, lack of access, lack of quality and the nontechnological generation. These challenges can be mediated by preparing the live-streaming services with the public in mind, remembering those in the margins, pre-recording the services and encouraging family fellowships. Coronavirus disease 2019 changes the way scholars study the relationship between media and religion. The study of media and religion cannot be performed without the consideration of challenges brought by the COVID-19 and the restrictions of the 
lockdown. Churches should really consider mastering the science of live-streaming as countries around the world face the second wave of COVID-19.

\section{Acknowledgements}

The author would like to thank the Department of Christian Spirituality, Church History and Missiology for the support provided in conducting this research.

\section{Competing interests}

The author declares that he has no financial or personal relationships that may have inappropriately influenced him in writing this article.

\section{Author's contributions}

This article is solely written by M.S.K.

\section{Ethical consideration}

The ethical clearance was issued by the University of South Africa, College of Human Sciences Research Ethics Review Committee (2019-CHS-90343018-Dept).

\section{Funding information}

This study was financially supported by the University of South Africa.

\section{Data availability statement}

Data sharing is not applicable to this article as no new data were created or analysed in this study.

\section{Disclaimer}

The views and opinions expressed in this article are those of the author and do not necessarily reflect the official policy or position of any affiliated agency of the author.

\section{References}

Badenhorst, N., 2020, Impact of COVID-19 on religious organisations, viewed 18 March 2020, from https://forsa.org.za/impact-of-covid-19-on-religious-organisations/

Badmos, K., 2014, 'Effect of social media on the church', in 2014 Annual Conference of theological friends and fellows, The Redeemed Christian Bible College, Lagos.

Bhengu, C., 2020, Bushiri charges followers R80 to 'praise' via his new app - Will you join?, viewed 21 April 2020, from https://www.timeslive.co.za/news/southafrica/2020-04-21-poll--bushiri-charges-followers-r80-to-praise-via-his-new-app will-you-join/.

Buheji, M., Da Costa Cunha, K., Beka, G., Mavric, B., De Souza, Y.L., Da Costa Silva, S.S. et al., 2020, 'The extent of COVID-19 pandemic socio-economic impact on global poverty: A global integrative multidisciplinary review', American Journal of Economics 10(4), 213-224. https://doi.org/10.5923/j.economics.20201004.02

Charles, M., 2020, COVID-19: Worshippers to find their Easter sermons on social media and YouTube, viewed 09 April 2020, from https://www.iol.co.za/capeargus/ news/covid-19-worshippers-to-find-their-easter-sermons-on-social-media-andyoutube- 46476821.

Dyer, O., 2020, 'COVID-19: Africa records over 10000 cases as lockdowns take hold', British Medical Journal 369(1), m1439. https://doi.org/10.1136/bmj.m1439
Fosu, G.O. \& Edunyah, G., 2020, Flattening the exponential growth curve of COVID-19 in Ghana and other developing countries: Divine intervention is a necessity, viewed 31 March 2020, from https://ssrn.com/abstract=3565147.

Gould, M., 2015, The social media gospel: Sharing the good news in new ways, Liturgical press, Collegeville, PA.

Iharare, 2020, Prophet Bushiri arrested during South African lockdown, viewed 26 April 2020, from https://iharare.com/prophet-bushiri-arrested-during-southafrican-lockdown/.

Isbell, T., 2020, 'COVID-19 lockdown in South Africa highlights unequal access to services', Afrobarometer dispatch no. 358, pp. 1-16, viewed 25 April 2020, from https://www.afrobarometer.org/publications/ad358-covid-19-lockdown-southafrica-highlights-unequal-access-services/

Jaja, I.F., Anyanwu, M.U. \& Iwu Jaja, C.J., 2020, 'Social distancing: How religion, culture and burial ceremony undermine the effort to curb COVID-19 in South Africa', Emerging Microbes \& Infections 9(1), 1077-1079. https://doi.org/10.1080/2222 1751.2020.1769501

Jones, R.D.J.H., 2020, What the online church can learn from online education, viewed 01 April 2020, from https://americananglican.org/wp-content/uploads/2020/04/ What-we-can-learn-from-online-education.pdf.

Kgatle, M.S., 2018, 'Social media and religion: Missiological perspective on the link between Facebook and the emergence of Prophetic Churches in Southern Africa', Verbum et Ecclesia 39(1), a1848. https://doi.org/10.4102/ve.v39i1.1848

Kreider, L., 2010, What every small-group leader should know: The definitive guide, Gospel Light Publications, Colorado Springs, CO.

Magongo, B., 2020, 'South Africa's social development sector response to COVID-19' National development agency, viewed 15 April 2020, from https://www.idinsight. org/reports-2/south\%20africas-social-development-sector-response-tocovid-19.

Mashau, T.D., 2014, 'Reimaining mission in the public square: Engaging hills and valleys in the African City of Tshwane', HTS Theological Studies 70(3), 1-11. https://doi.org/10.4102/hts.v70i3.2774

Mashau, T.D. \& Mangoedi, L., 2015, 'Faith communities, social exclusion, homelessness and disability: Transforming the margins in the City of Tshwane', HTS Theological Studies 71(3), 1-09. https://doi.org/10.4102/hts.v71i3.3088

Mathe, T., 2020, 'Churches are struggling in lockdown', Mail \& Guardian, viewed 07 May 2020, from https://mg.co.za/business/2020-05-07-churches-are-strugglingin-lockdown/

Moynagh, M., 2014, Being church, doing life: Creating Gospel communities where life happens, Monarch Books, Grand Rapids, MI.

Mothombeni, A., 2020, Bushiri defends request for tithes, offerings, viewed 06 April 2020, from https://sundayworld.co.za/news/bushiri-defends-request-for-tithesofferings/.

NICD, 2020, First case of COVID-19 coronavirus reported in SA, viewed 05 March 2020 from https://www.nicd.ac.za/first-case-of-covid-19-coronavirus-reported-in-sa/.

Pikoli, Z., Demolitions despite lockdown place residents at risk, viewed 01 April 2020 from https://www.dailymaverick.co.za/article/2020-04-01-demolitions-despitelockdown-place-residents-at-risk-2/\#gsc.tab=0.

Ozili, P.K., 2020a, COVID-19 in Africa: Socioeconomic impact, policy response and opportunities, MPRA Paper No. 99617, Posted 17 April 2020, 10:55 UTC, viewed 13 April 2020, from https://mpra.ub.uni-muenchen.de/99617/.

Ozili, P.K., 2020b, COVID-19 pandemic and economic crisis: The Nigerian experience and structural causes, MPRA, viewed 08 April 2020, from https://mpra.ub.uniand structural causes,
muenchen.de/99424/.

Reddy, S., 2020, 1 in 2 South Africans believe they're not at risk to contract COVID-19: HSRC Survey, viewed 26 April 2020, from https://www.sabcnews.com/sabcnews/1 in-2-south-africans-believe-theyre-not-at-risk-to-contract-covid-19-hsrc-survey/.

Shoba, S., 2020, As the modified lockdown kicks in, social media, faith, backyard dribbling friends and family keep us going, viewed 30 April 2020 ,rom https://www dailymaverick co za/article/2020-04-30-as-the-modifiedlockdown-kicks-in-social-media-faith-backyard-dribbling-friends-and-familykeep-us-going.

South African Government, 2020, President Cyril Ramaphosa: Escalation of measures to combat coronavirus COVID-19 pandemic, viewed 23 march 2020, from https:// www.gov.za/speeches/president-cyril-ramaphosa-escalation-measures-combatcoronavirus-covid-19-pandemic-23-mar.

Thompson, P., 2020, How to live stream your church service: A practical guide, viewed 12 March 2020, from https://www.thegospelcoalition.org/article/livestreamchurch-service-practical-guide/.

Vedfelt, K., 2020, Our research shows why it's vital to protect older South Africans from coronavirus, viewed 26 April 2020, from https://theconversation.com/ our-research-shows-why-its-vital-to-protect-older-south-africans-fromcoronavirus-136648.

WHO, 2020, Naming the coronavirus disease (COVID-19) and the virus that causes it, viewed 20 April 2020, from https://www.who.int/emergencies/diseases/novelcoronavirus-2019/technical-guidance/naming-the-coronavirus-disease-(covid2019)-and-the-virus-that-causes-it.

Wielstra, S., 2012, 'Social media and the church: A systematic literature review', In 17th Twente Student Conference on IT, June 25, viewed from https://pdfs. semanticscholar.org/b175/7eef164f202b87f3885607cd0d57d6e73756.pdf. 